\title{
Neutrophil-Lymphocyte Ratio as a Predictor of Bacterial Meningitis in Children
}

\author{
Ferry Yulianto, Dewi Sutriani Mahalini*, I Gusti Ngurah Made Suwarba \\ Sanglah Hospital, Neurology Division-Department of Pediatrics, Udayana University, Denpasar-Bali, Indonesia
}

\section{Email address:}

dewi_sutriani@unud.ac.id (D. S. Mahalini)

${ }^{*}$ Corresponding author

\section{To cite this article:}

Ferry Yulianto, Dewi Sutriani Mahalini, I Gusti Ngurah Made Suwarba. Neutrophil-Lymphocyte Ratio as a Predictor ofBacterial Meningitis in Children. Clinical Neurology and Neuroscience. Vol. 5, No. 2, 2021, pp. 30-34. doi: 10.11648/j.cnn.20210502.16

Received: May 11, 2021; Accepted: May 26, 2021; Published: June 4, 2021

\begin{abstract}
Diagnosis of bacterial meningitis in children is difficult. Both bacterial and aseptic meningitis have identical clinical presentation. Cerebrospinal fluid (CSF) analysis and microbacterial culture are modalities to help physician distinguishing between both of them. However, lumbar puncture procedure to gain CSF sample could not always be done due to contraindications or clinically unstable condition. Blood Neutrophil Lymphocyte Ratio (NLR) examination has a potential biomarker to differentiate causes of meningitis when CSF sample cannot be obtained, especially in the early phase of disease. This study's objective is to determine whether the NLR value can be used as a predictor of bacterial meningitis in children. The research design was cross-sectional. Data was taken retrospectively by reviewing medical records at Sanglah Hospital, Denpasar for the period January 2017 to December 2020. Data taken were age, sex, leukocyte, neutrophils, lymphocytes count and cerebrospinal fluid culture. Analysis of NLR in conjunction with bacterial and aseptic meningitis was carried out. During the study period, a total of 100 data samples were obtained, 58 subjects were male and 42 female subjects. Non-bacterial meningitis and aseptic meningitis were found in 62 cases, while bacterial meningitis with positive CSF culture results was found in 38 cases. ROC curve analysis showed the optimal cut-off value for NLR was 5.64 which resulted in a sensitivity of 0.84 and a specificity of 0.51. The Area Under the Curve (AUC) value for the NLR was 0.67 (CI95\% 0.56-0.78, $\mathrm{p}=0,003$ ) with positive and negative predictive values being $0.41(0.28-0.54)$ and $0.63(0.56-0.7)$, respectively. NLR $\geq 5.64$ can be used as one of the predictors for diagnosing bacterial meningitis in children.
\end{abstract}

Keywords: Neutrophil Lymphocyte Ratio, Bacterial Meningitis, Predictor

\section{Introduction}

Meningitis is a severe acute infection of the Central Nervous System (CNS) which causes inflammation of the meninges, the membrane that covers the brain and spinal cord [1]. Meningitis is broadly divided into 2 groups based on etiology, bacterial and aseptic. Bacterial infection as the etiology of meningitis needs to be distinguished from aseptic meningitis because antibiotic management is necessary to be given in the early course of illness in bacterial meningitis as either empirical or definitive therapy. Failure to detect bacterial meningitis earlier will result in delayed administration of antibiotic therapy, which can lead to high morbidity and mortality as well as fatal and permanent neurologic sequelae [2].

Based on The Global Burden of Disease (GBD) in 2016, the global incidence of meningitis increased from 2.5 million in 1990 to 2.82 million in 2016 [3]. Deaths due to meningitis decreased by $21 \%$ from 1990 to 2016 globally since the development of vaccinations. However, owing to high mortality rate and sequelae caused by bacterial meningitis, this case requires early and comprehensive treatment [4]. Before the mandatory of the pneumococcal conjugate vaccination, cases of bacterial meningitis in the United States reached 6,000 cases per year and half of these cases occurred in children below 18 years old [5]. In Niamey, Nigeria, the average bacterial meningitis cases is 101 per 100,000 populations every year [6]. Meanwhile, a study conducted in Asia, China, incidence of acute bacterial meningitis in children less than 5 years old was 12.4 to $19.2 / 100,000$ cases [7]. In Indonesia, the country which this study was conducted, bacterial meningitis cases reached 158/100,000 cases per year 
$[8,9]$. The mortality rate in patients treated with antibiotic therapy is about $10 \%$ of reported cases, while the mortality rate in untreated cases is $50-90 \%$ [10].

Prompt and accurate diagnosis of bacterial meningitis in children is very important to avoid complications, neurological deficits or even death, but on the other hand, giving antibiotics too early can increase possibility of bacterial resistance and lead to high hospitalization cost burden due to inappropriate use antibiotics [11]. Various clinical and supporting biomarkers as well as a scoring system have been developed to aid medical personnel to diagnose bacterial meningitis.

In general, bacterial meningitis is characterized by an increase in neutrophil (polymorphonuclear) cells in the cerebrospinal fluid. Therefore, to support the diagnosis, a biomarker that easily calculated and quickly available is needed. Neutrophil Lymphocyte Ratio (NLR) is one of the inflammatory biomarker that has been studied as a predictor of mortality in heart disease, prognostic factor of malignant diseases, and biomarker of inflammation due to bacterial infection [12, 13, 14]. NLR is obtained by dividing the absolute neutrophil count with absolute lymphocyte count [15]. Since NLR combines neutrophils and lymphocytes count on its calculation, this marker is considered to be more stable than absolute neutrophil count separately [16].

Various studies have evaluated the relationship between NLR and diverse bacterial infections. Neutrophil lymphocyte ratio has been reported as a predictor of severity and clinical outcome in patients with community-acquired pneumonia or bacteremia [17-19]. This marker can be used also as a predictor in sepsis patients who are admitted to the Pediatric Intensive Care Unit (PICU) [20]. The objective of this study is to find correlation between NLR as a predictor of bacterial meningitis in children.

\section{Method and Material}

This study used a cross-sectional design with data taken retrospectively from medical records to assess the Neutrophil Lymphocyte Ratio (NLR) as a predictor in pediatric patients with bacterial meningitis. The research was carried out at medical record installation at Sanglah Hospital in Denpasar by taking data on suspected meningitis cases who had been admitted during January 2017 to December 2020 period.

The sampling method in this study was purposive sampling. Each patient who met the criteria was included in the study until the required number of samples was met. NLR value was evaluated in correlation with descriptive, binomial variable results (bacterial meningitis or non-bacterial/aseptic meningitis). The minimum sample size in this study was 91 children with suspected meningitis.

The inclusion criteria were infants with age range of 1 month old to 18 years old with suspected meningitis (clinical signs and symptoms of meningitis and done lumbar puncture procedure, with CSF analysis results showed pleocytosis $>$ $20 / \mathrm{mm} 3$ and/or increased CSF protein $>50 \mathrm{mg} / \mathrm{dL}$ and/or decreased CSF glucose $<60 \%$ serum glucose) and CSF culture was carried out as the gold standard for diagnosis of bacterial meningitis. Exclusion criteria included incomplete medical records and bacterial meningitis due to post neurosurgical procedure. Independent variable in this study was Neutrophil Lymphocyte Ratio (NLR), which is the ratio of serum Absolute Neutrophil Count (ANC) with Absolute Lymphocytes Count (ALC). Dependent variables for this study were bacterial meningitis (confirmed by the presence of pathogens in cerebrospinal fluid $\{\mathrm{CSF}\}$ culture) and nonbacterial/aseptic meningitis (meningitis not caused by bacterial infection, with negative CSF culture results).

From the existing data, the NLR data were collected and then statistical analysis was carried out with descriptive analysis of the Receiver Operating Characteristic (ROC) output curve to receive percentage from Area Under the Curve (AUC) using the $23^{\text {rd }}$ version SPSS software for Windows. The NLR index was emphasized to the cut-off value with high sensitivity result for the purpose of screening bacterial meningitis cases. Determination of the cut-off point was done analytically using Youden index. Data analysis using 95\% confidence intervals and $p$ value $<0.05$ was considered statistically significant.

This study had obtained ethical clearance from the Research and Development Unit of the Faculty of Medicine, Udayana University/Sanglah Hospital No: 2491/UN14.2.2. VII. 14/LT/2020. Research permit was obtained from the Research Ethics Commission of the Faculty of Medicine, Udayana University/Sanglah General Hospital Denpasar No: LB. 02.01/XIV. 2. 2.1/2072/2021.

\section{Result}

One hundred data samples were taken from pediatric patients with suspected meningitis. Of the total subjects, 58 subjects were male and 42 subjects were female. Non-bacterial meningitis/aseptic meningitis was found in 62 cases, whereas bacterial meningitis with positive CSF culture results was found in 38 cases, thus, the prevalence of bacterial meningitis was $38 \%$. Of the aseptic meningitis group, 35 subjects were male and 27 female. Meanwhile, from the bacterial meningitis group, 23 subjects were male and 15 female.

Table 1. Characteristics of Subjects.

\begin{tabular}{lll}
\hline \multirow{2}{*}{ Characteristics } & Category; Median $(\mathbf{m i n}-\mathbf{m a x})$ & Non Bacterial Meningitis N=62 \\
\cline { 2 - 3 } & Bacterial meningitis N=38 & $24(2-206)$ \\
Age (month) & $20.5(2-176)$ & $35(56.4)$ \\
Male, $\mathrm{n}(\%)$ & $23(60,5)$ & $27(43.6)$ \\
Female, $\mathrm{n}(\%)$ & $15(39,5)$ & $9.9(1.5-38.05)$ \\
White Blood Cell count $\left(10^{3} / \mu \mathrm{L}\right)$ & $15.76(6.4-35.75)$ & \\
\hline
\end{tabular}




\begin{tabular}{lll}
\hline \multirow{2}{*}{ Characteristics } & Category; Median (min-max) & \\
\cline { 2 - 3 } & Bacterial meningitis N=38 & Non Bacterial Meningitis N=62 \\
\hline $\mathrm{ANC}^{1}\left(10^{3} / \mu \mathrm{L}\right)$ & $11.33(2.77-26.52)$ & $5.51(0.49-35.52)$ \\
$\mathrm{ALC}^{2}\left(10^{3} / \mu \mathrm{L}\right)$ & $2.33(0.57-11.23)$ & $1.94(0.49-7.07)$ \\
$\mathrm{NLR}$ & $3.39(0.58-31.3)$ & $3.38(0.29-34.15)$ \\
\hline
\end{tabular}

${ }^{1}$ Absolute Neutrophil Count

${ }^{2}$ Absolute Lymphocyte Count

Based on the ROC curve, the AUC value obtained was 0.67 (CI 95\%, 0.56-0.78), $p=0.003$ compared to the $50 \%$ index, which means that if the NLR value is used to diagnose the presence or absence of bacterial meningitis in 100 patients, then correct conclusions will be obtained in 67 patients. The cut-off value of 5.64 was determined by statistical methods using the Youden index which had the highest sensitivity value of 0.84 and a specificity of 0.51 .

Table 2. Several NLR cut-off values obtained from the ROC curve.

\begin{tabular}{lllll}
\hline NLR Cut-off & Sensitivity & Specificity & PPV $^{\mathbf{1}}(\mathbf{C I 9 5 \% )}$ & NPV $^{\mathbf{2}}$ (CI95\%) \\
\hline 5.64 & 0.84 & 0.51 & $0.41(0.28-0.54)$ & $0.63(0.56-0.7)$ \\
6.82 & 0.73 & 0.58 & $0.37(0.24-0.53)$ & $0.61(0.55-0.67)$ \\
8.68 & 0.65 & 0.64 & $0.45(0.27-0.64)$ & $0.93(0.75-1.15)$ \\
\hline
\end{tabular}

${ }^{1}$ Positive Predictive Value

${ }^{2}$ Negative Predictive Value

Table 3. Association between bacterial meningitis with several NLR cut-offs value.

\begin{tabular}{|c|c|c|c|c|}
\hline & & Bacterial Meningitis & Non Bacterial Meningitis & Total \\
\hline \multirow{6}{*}{ NLR } & $\geq 5.64$ & 14 & 20 & 34 \\
\hline & $<5.64$ & 24 & 42 & 66 \\
\hline & $\geq 6.82$ & 11 & 18 & 29 \\
\hline & $<6.82$ & 27 & 44 & 71 \\
\hline & $\geq 8.68$ & 9 & 12 & 21 \\
\hline & $<8.68$ & 29 & 50 & 79 \\
\hline
\end{tabular}

NLR 5.64, at the $95 \%$ confidence interval, had positive predictive value of $0.41(0.28-0.54)$ and negative predictive value of $0.63(0.56-0.7)$, while NLR 8.68 had positive predictive value of $0.45(0.27-0.64)$ and highest negative predictive value of $0.93(9.75-1.15)$.

\section{Discussion}

Bacterial meningitis is an infectious disease involving central nervous system, which associated with high morbidity and mortality [22]. Diagnosis of bacterial meningitis becomes crucial because early antibiotic therapy affects the outcome, so that diagnosis is important to avoid complications of neurological deficits or death, but on the other hand, improper administration of antibiotics increases bacterial resistance and the higher cost of hospitalization [11].

Cerebrospinal fluid (CSF) culture is a microbiological diagnostic that becomes standard for diagnosing bacterial meningitis definitively. However, CSF culture sampling through lumbar puncture procedure cannot always be done immediately. The examination result takes time and positive results are not always obtained. Desai stated that the fastest time needed to see the presence of CSF culture was 3 days $(75.2 \%)$ and $24.8 \%$ required a longer incubation time $\geq 4$ days [23]. Study by Alam in West Java, Indonesia involving children age 6-18 months old showed positive CSF culture results were only found in $27.7 \%$ of cases regardless of previous history of antibiotics [8].

In our study, during period January 2017 to December 2020, a sample of 100 cases with suspected meningitis was obtained. Thirty-eight subjects showed positive CSF culture results (bacterial meningitis) which were subsequently assigned to the bacterial meningitis group and 62 subjects with negative
CSF culture as the non-bacterial meningitis group.

The median age from bacterial meningitis and nonmeningitis cases groups were 20.5 and 24 months, respectively. The results of this study are in line with that conducted by Mahalini et al, the median age of bacterial meningitis in children is 29.8 months ( $\mathrm{SD} \pm 32.1$ ) [24]. Randolph et al stated that after 2 years of life that the innate and acquired immune responses have just developed mimicking the immune response levels of healthy adults [25]. The function of immune system at younger age or infants is more susceptible to severe infections caused by pathogenic microorganisms, in particular viruses or encapsulated bacteria. In children under 2 years of age, the production of IFN- is quite low and the response of cytotoxic $\mathrm{T}$ cells has not been developed optimally hence this age group more susceptible to severe infections, including meningitis [26].

The number of white blood cells/leukocytes in the bacterial meningitis group was higher with a median of 15.76 (6.4-35.75) x $10^{3} / \mu \mathrm{L}$ compared to the non-meningitis group of $9.9(1.5$ $38.05) \times 10^{3} / \mu \mathrm{L}$. Leukocytosis was also found according to study conducted by Mahalini in cases of bacterial meningitis (median $16.9 \times 10^{3} / \mu \mathrm{L}$ ) compared to the non-bacterial meningitis group (median $12.1 \times 10^{3} / \mu \mathrm{L}$ ) [24]. Likewise, the ANC in bacterial meningitis group had median 11.33 (2.77$26.52) \times 10^{3} / \mu \mathrm{L}$ and $5.51(0.49-35.52) \times 10^{3} / \mu \mathrm{L}$ in the bacterial non-meningitis group. Leukocytes are units of blood cells that move in the body's immune defense system. Leukocytosis is 
an increase in white blood cells, which is a biomarker of infection. Neutrophil is predominant phagocytic cell type produced by granulocytic progenitor cells when there is inflammation due to bacterial infection. Neutrophil infiltration in tissues reaches a peak within 6 hours [27]. As the production of neutrophils in the bone marrow increases, these cells engulf and destroy bacteria intracellularly. Neutrophil granules, which contain an arsenal of microbial proteins, bind with the ingested invading bacteria by phagocytosis and kill them inside the cell. Neutrophils can also release bacteriakilling chemicals into the extracellular fluid through exocytosis of the granule contents out of the cell $[19,27]$.

In our study, the median NLR in bacterial meningitis group was $3.39(0.58-31.3)$. AUC value obtained to predict bacterial meningitis in 100 study subjects was 0.67 . In the process of determining the cut point, the researchers obtained 2 optimal cut-off points statistically using the Youden index method (NLR cut-off value of 5.64, sensitivity 0.84 , specificity 0.51 ) and using method of the intersection of the sensitivity and specificity curves (NLR cut-off value of 8.68 , sensitivity 0.65 , specificity 0.64 ). Referring to the research objective, the NLR value is emphasized on higher sensitivity value, so that the NLR 5.64 is considered to be more appropriate in this study. NLR value of 5.64 has a positive predictive value of 0.41 $(0.28-0.54)$ and a negative predictive value of $0.63(0.56-$ $0.7)$. With this cut-off value, it could be used to screen as many cases as possible that lead to bacterial meningitis hence empiric antibiotic can be started if there is any contraindication to LP procedure prior to antibiotic therapy.

Based on study by Mentis, et al, to determine the relationship between the NLR and bacterial meningitis in children, the optimal NLR was 8 [1]. This NLR value is in line with the study result of the cutoff point value of 8.68 obtained from the sensitivity and specificity curve intersection graph method which has a positive predictive value of $0.45(0.27$ $0.64)$ and a negative predictive value of $0.93(0.75-1.15)$. This intersection point has a higher specificity, which could be used for diagnosis rather than screening purpose.

NLR combines neutrophils and lymphocytes in the calculation, so it is considered more stable than the absolute number of neutrophils and lymphocytes [16]. Compared with other markers of infection, the NLR is quite easy to obtain on complete blood counts examination and does not require special instruments. Changes in leukocyte levels occur rapidly due to the release of neutrophils and decreased lymphocyte levels as an initial response to inflammation caused by infection, including bacterial meningitis. Increased level of neutrophils or neutrophilia result from neutrophil dermargination, delayed neutrophil cell apoptosis and stimulation induced by inflammatory cytokines and growth factors. The processes of redistribution, margination and increased apoptosis are mechanisms that are thought to cause lymphocytopenia in infectious diseases caused by bacteria [19]. NLR has been studied as a marker of inflammation due to bacterial infection. Yullyantara et al have also reviewed that an NLR value $\geq 4.67$ is a risk factor for the occurrence of bloodstream infection (bacteremia) in children [21]. Our study has several drawbacks. Previous antibiotic use history was not excluded in this study, so further studies are needed to confirm the study results. Data study was also obtained retrospectively, so further studies with a larger sample with prospective method are needed to confirm the study results.

\section{Conclusion}

NLR $\geq 5.64$ can be used as a predictor in predicting bacterial meningitis in children in order not to delay empirical antibiotic therapy, especially when CSF analysis could not be obtained immediately due to limitation/clinical contraindications. However, NLR is not a good biomarker to be used alone for diagnosing bacterial meningitis. Diagnosis of bacterial meningitis in children must be adjusted clinically and correlated with other biomarkers and diagnostic modalities. Accordingly NLR can be considered as a component of the scoring system for the diagnosis of bacterial meningitis.

\section{Disclosure}

All the authors do not have any possible conflict of interest.

\section{References}

[1] Mentis AF, Kyprianou MA, Xirogianni A, Kesanopoulos K, Tzanakaki G. Neutrophil-to-lymphocyte ratio in the differential diagnosis of acute bacterial meningitis. European Journal of Clinical Microbiology \& Infectious Diseases. 2016; 35 (3): 397-403.

[2] Van de Beek D, Brouwer MC, Thwaites GE, Tunkel AR. Advances in treatment of bacterial meningitis. Lancet. 2012; 380: 1693-702.

[3] Zunt JR, Kassebaum NJ, Blake N, Glennie L, Wright C, Nichols $\mathrm{E}$ et al. Global, regional, and national burden of meningitis, 1990-2016: a systematic analysis for the Global Burden of Disease Study. Lancet Neurol. 2018; 17 (12): $1061-82$

[4] World Health Organization. Defeating meningitis by 2030. In Proceedings of the First Meeting of the Technical Taskforce. 2018.

[5] Sáez-Llorens X, McCracken Jr, GH. Bacterial meningitis in children. The lancet. 2003; 361 (9375): 2139-48.

[6] Campagne G, Schuchat, A Djibo S, Ousseini A, Cisse L, Chippaux JP. Epidemiology of bacterial meningitis in Niamey, Niger, 1981-96. Bulletin of the World Health Organization. 1999; 77 (6): 499.

[7] Li Y, Yin Z, Shao Z, Li M, Liang X, Sandhu HS et al. Population-based surveillance for bacterial meningitis in China, September 2006-December 2009. Emerging infectious diseases. 2014; 20 (1): 61.

[8] Alam A. 'Kejadian Meningitis Bakterial pada Anak usia 6-18 bulan yang menderita Kejang Demam Pertama'. Fakultas Kedokteran Universitas Padjajaran. Sari Pediatri. 2011; 13 (4): 293-8. 
[9] Kristianti GH, Made-Suwarba IGN, Mahalini DS, Gustawan IW, Dwilingga-Utama MG. 'Bacteria and Antibiotic Susceptibility Patterns of Cerebrospinal Fluid Isolated in Children with Bacterial Meningitis at Sanglah Hospital, Bali from 2016 to 2018'. Clinical Neurology and Neuroscience. 2020; Vol. 4, No. 3: 51-6.

[10] Yanuar W, Sari IP, Nuryastuti T. Evaluation of Empiric Antibiotic Therapy Toward Clinical Outcome in Children Patients with Bacterial Meningitis in Dr. Sardjito General Hospital Yogyakarta 2010-2015. Majalah Farmaseutik. 2018; 14 (2): 49-53.

[11] Proulx N, Frechette D, Toye B, Chan J, Kravcik S. 'Delays in the administration of antibiotics are associated with mortality from acute bacterial meningitis'. QJM. 2005; 98: 291-8.

[12] Bhat T, Teli S, Rijal J, Bhat H, Raza M, Khoueiry G et al. Neutrophil to lymphocyte ratio and cardiovascular diseases: a review. Expert Rev Cardiovasc Ther. 2013.; 11: 55-9.

[13] Templeton AJ, McNamara MG, Šeruga B, Vera-Badillo FE, Aneja P, Ocana A et al. Prognostic role of neutrophil to lymphocyte ratio in solid tumors: a systematic review and meta-analysis. J Natl Cancer Inst. 2014; 106: dju 124.

[14] Forget P, Khalifa C, Defour JP, Latinne D, Van Pel MC, De Kock M. What is the normal value of the neutrophil-tolymphocyte ratio? BMC research notes. 2017; 10 (1): 12.

[15] Nurdani A, Hadi U, Arfijanto MV, Miftahussurur M. Neutrophil-lymphocyte ratio and procalcitonin levels in sepsis patient. The New Armenian Medical Journal. 2019; 13 (01): 48-54.

[16] Dirican A, Kucukzeybek BB, Alacacioglu A, Kucukzeybek Y, Erten C, Varol U et al. Do the derived neutrophil to lymphocyte ratio and the neutrophil to lymphocyte ratio predict prognosis in breast cancer? Int J Clin Oncol. 2015; 20: 70-81.

[17] De Jager CPC, Wever PC, Gemen EFA, Kusters R, van Gageldonk-Lafeber AB, van der Poll et al. The neutrophillymphocyte count ratio in patients with community-acquired pneumonia. PLOS ONE. 2012; 7: e46561.
[18] Loonen AJ, de Jager CP, Tosserams J, Kusters R, Hilbink M, Wever PC et al. Biomarkers and molecular analysis to improve bloodstream infection diagnostics in an emergency care unit. PloS ONE. 2014 Jan 27; 9 (1): e87315.

[19] Kartal O, Kartal AT. Value of neutrophil to lymphocyte and platelet to lymphocyte ratios in pneumonia. Bratisl Med J. 2017; 118 (9): 513-6.

[20] Dursun A, Ozsoylu S, Akyildiz BN. Neutrophil-to-lymphocyte ratio and mean platelet volume can be useful markers to predict sepsis in children. Pakistan Journal of Medical Sciences. 2018; 34 (4): 918.

[21] Yullyantara S, Gustawan W, Dwilingga Utama MG, Arhana BNP. Rasio NLCR sebagai faktor risiko terjadinya infeksi bakteri. Sari Pediatri. 2019. Vol. 20, No. 6, April 2019.

[22] Prasad K, Kumar A, Singhal T, dan Gupta PK. 'Third generation cephalosporins versus conventional antibiotics for treating acute bacterial meningitis'. Cochrane Database of Systematic Reviews. John Wiley \& Sons, Ltd, Chichester, UK. 2007.

[23] Desai A, Lollis S. 'How long should cerebrospinal fluid cultures be held to detect shunt infections?'. J Neurosurg Pediatrics. 2009; 4.

[24] Mahalini, DS, Sudewi, AAR, Soetjiningsih, Widiana, IGR. The accuracy of cerebrospinal fluid and serum S100B protein to diagnose bacterial meningitis in children at pediatric ward Department of Child's Health, Sanglah Hospital Denpasar, Bali-Indonesia. Bali Medical Journal. 2018; 7 (3): 601-6. doi: 10.15562/bmj.v7i3.1202.

[25] Randolph AG, McCulloh R. Pediatric sepsis. Virulence. 2014; 5: $179-89$.

[26] Naess A, Nilssen SS, Mo R, Eide GE, Sjursen H. Role of neutrophil to lymphocyte and monocyte to lymphocyte ratios in diagnoses of bacterial infection in patients with fever. Infection. 2017; 45: 299-307.

[27] Riley LK, Rupert J. Evaluation of patients with leukocytosis. American family physician. 2015; 92 (11): 1004-11. 